\title{
Kapitel 6
}

\section{Den levende handling}

\author{
af Søren Damkjoer
}

\section{Et ideal}

Betegnelsen »den levende handling « benytter Niels Bukh i en moden alder som en sammenfatning at sit eget syn på gymnastik og idræt. *) Dermed refererer han naturligvis til højskolebevægelsens levende ord. Hans aktiviteter som gymnastikpædagog og højskolemand finder sted i slutningen af højskolens tredie periode og kulminerer i dens fjerde periode, fra 1920 til $1950 .{ }^{2}$ ) Denne periode har på mange måder sin egen distinkte karakter i dansk idrætshistorie, ikke mindst gennem Niels Bukhs centrale position.

Niels Bukhs ideer og synspunkter på gymnastik, idræt og legemskultur blev formuleret $i$ »Primitiv Gymnastik « tidligt i ty verne, kort efter grundlæggelsen af den første gymnastikhøjskole (1920). Der er i bogen et kortfattet program eller vision, om man vil, ligesom gymnastikhøjskolen dannede de fysiske rammer for en virkeliggørelse. Som bekendt blev rammerne udvidet $i$ en hurtig takt.

"Selvom nu menneskeidealet har varet noget forskelligt for de forskellige tider og nationer, er een type eller een holdning dog vist nogenlunde tilfredsstillende for alle tider og alle nationer, den nemlig, hvor smidighed, kraft og behandighed er forenet i harmonisk skonhed, og mod den holdning stiler primitiv gymnastikw. ${ }^{3}$ )

„Eller tank på kunstneren, der tager leret $i$ sin hånd. Han begynder ikke straks at tumle med enkelthederne, men knuser, opbloder og alter materialet, til det bliver fojeligt og bøjeligt $i$ hans hånd, og så forst begynder han at forme og krceve, at materialet skal give udtryk for, hvad der bor $i$ ham, og at han, ved at give sig helt hen $i$ arbejdet, kanfylde det med, så det bliver et kunstvark, der udtrykker netop det, som hans mål var. “ ${ }^{4}$ )

"- thi herken en arbejdsmåde, som denne eller et gymnastiksystem som det Ling'ske kan begranses afen bestemt ovelsesrakke". ${ }^{5}>$

"Hver gang jeg erfarer mig til en ny ovelse eller arbejdsmåde, der kan tjene sagen, og her gang, jeg hos andre ser gymnastisk arbejde, som jeg kan bruge, enten som det er, eller i andret form, fojer jeg også med glade det til arbejdet -r. 6) 
»På det grundlag, der med denne arbejdsmåde kan lagges for legemskultur, kan der bygges videre med idrots gymnastik, som jeg ad àre vil prove at skrive en bog om, eller medfri idrat, som min tredie bog skal omhandle «. ")

"Skal gymnastikken alene klare den legemlige dannelse, da må den også bemytte idrcetslige ovelser, der tager mennesket som helhed i brug - både i lette, fint afstemte bevegelser og i fardigheder, der kraver sterkt koncentreret og fuldkommen behersket kraftudfoldelse«. ${ }^{8}>$

"Gymnastik og Idrcet kan naturligvis hverfor sig tjene ungdommens legemlige udvikling og styrke dets karakter, men bedst ville det vare, om de kunne virke sammen. Og derfor er det mit ønske, at delingsforere i fremtiden også vil pătage sig ledelsen af boldspil, svomning og de ovrige frie idratter og fore disse vardifulde virkemidler $i$ ungdomsarbejdet frem til virkelig folkegavn på samme udmarkede måde, som de har fort gymnastikken frem her $i$ Danmark. ${ }^{9}$ )

I disse citater ses Niels Bukhs egen formulering af et legemligt ideal og midlerne til at virkeliggøre det, dvs. det middel, der lå $\mathrm{i}$ hans egen ny skabelse, grundgymnastikken, og de midler, der forelå i idrætsgymnastikken (stillingsgymnastikken og spring), i den frie idræt og i boldspillene. Det højeste mål, legemlig fuldkommenhed, skulle virkeliggøres gennem et hieraki af gymnastiske og idrætslige virkemidler med grundgymnastikken som første led. Målet var en folkegymnastik og folkeidræt. Virkeliggørelsen blev til baggrunden for hans position i en menneskealder.

\section{En central position}

Når man betragter gymnastikken og idrætten i Danmark imellem 1920 og 1950 er Niels Bukhs position iøjnefaldende. Hvis man lidt ubeskedent kalder denne periode for en epoke, gymnastikkens storhedstid med tyngdepunkt i bondekulturen, må man spørge sig, hvad der betingede dette. Jeg tror, at forklaringen kan ligge i den selvstcendiggorelse af det gymnastiske ideal, som Niels Bukh repræsenterede. Derved kunne han imødekomme de sociale behov om en mere selvstændig gymnastik- og idrætskultur, der opstod efterhånden som gymnastikkens stærke bidrag til den forrige periodes politiske, nationale og kulturelle kamp blev løsnet. Denne løsnelsesproces tog til i styrke under og efter Første Verdenskrig. Han kunne med sin »formel« og sin skolevirksomhed så at sige befordre gymnastikkens selvstændiggørelse og samtidig forudgribe den frie idræts vækst, i hver fald for en tid. Med sin nye høj skoleform, gymnastikhøjskolen, kunne han udvide og uddybe højskolegymnastikkens virkefelt. Hans egen nyskabelse, grundgymnastikken, i kombinaiton med perfektioneringen af idrætsgymnastikken, udgjorde en ny og selvstændig model for legemskultur, og blev kærnen i hans centrale position. Nogle af disse påstande vil senere blive uddybet.

Der er en del indikatorer på hans centrale position. I slutningen af tyverne havde han uddannet ca. 3000 delingsførere, formentlig lidt under halvdelen 
af samtlige. ${ }^{19}$ ) På det tidspunkt var den primitive gymnastik også slået igennem. Som forstander på sin egen gymnastikhøjskole havde han en uafhængig position i forhold til De Danske Skytte- og Gymnastikforeninger. Uden her at komme ind på organisationsspergsmålet som sådant, var Niels Bukhs tanker om en enhedsorganisation præget af hans principielle syn på gymnastikkens og idrættens mission og blev ligeledes formuleret tidligt i tyverne. Da hans egen høj skoleform havde en særlig tæt forbindelse med de folkelige organisationer, gennem uddannelsen af delingsforere, havde hans synspunkter en betydelig vægt.

Disse synspunkter var i øvrigt også fremsat i Primitiv Gymnastik, hvor han advarede mod dvaskhed og manglende ansvarsfolelse fra neden og partivæsen og organisationsiver fra oven og henviser til, »at et samfund, der består af mange personligheder med ansvarsfølelse er stærkere og lever rigere end et, hvor kun enkelte tænker og derved erhverver sig ansvar og ledelse af de mange «. " ${ }^{\text {"I }}$ ) Som en form for »delingsforernes delingsforer « gjorde han sig til talsmand for stærke ideale krav i ungdoms- og gymnastikorganisationerne. Også dette krav gav ham en betydelig position. En nærmere bestemmelse af indholdet i Niels Bukhs ideologiske og politiske synspunkter vil jeg undlade i denne sammenhæng, selv om det naturligvis er væsentligt. Jeg hælder til at betragte dem ud fra hans gymnastiske idealer, og hæfter mig ved, at de i hovedtræk allerede fremsættes tidligt $i$ tyverne og må have været dannet tidligere, formentligt under indtryk af Danmarks stilling under Første Verdenskrig og sammenbruddet af det internationale politiske system. Resultatet var en stærkt idealistisk betoning af ungdoms- og gymnastikarbejdets mission både i Danmark og internationalt, en slags »transpolitisk« kulturpolitik. Uanset det endelige svar på dette sporgsmål, så var disse synspunkter medvirkende til, at han indtog den position, han gjorde, som talsmand for en stærkt idealistisk opfattelse af en idrætsorganisations opgaver. Hans position var i betydelig grad knyttet til hans personlighed, som personifikation af en mere og mere selvstændig gymnastik- og idrætskultur. Som jeg vil forsøge at vise i det folgende, må en analyse tage sit udgangspunkt i den autonomiseringsproces af gymnastik og idræt, som han var eksponent for. Det var den »magiske formel «, dvs. forbindelsen af grundgymnastik, idrætsgymnastik og fri idræt og dens perfektionering, der gjorde, at han kunne indtage den position han gjorde. Denne proces fik en for Danmark specifik form igennem gymnastikhojskolen som hojskoleform.

\section{En historisk-sociologisk synsvinkel}

Gymnastikken repræsenterer som kulturelt fænomen en speciel moderne konfiguration af praktikker og ideologier med henblik på kropsbeherskelse. Det centrale i den "gymnastiske konfiguration « er ideen om en rationel og artificiel bearbejdelse af legemet gennem et sæt af øvelser, der tillægges særlige kropslige og pædagogiske effekter i forhold til et sæt af kulturelle normer og 
værdier. De forskellige gymnastiksystemer adskiller sig fra hinanden gennem udformningen af ovelser og kropsteknikker, gennem vurderingen af de kropslige og pædagogiske effekter og gennem de normer og værdier for kropslig fuldkommenhed, som systemet appelerer til. Derved forbindes gymnastikken med bestemte sociale gruppers sociale og kulturelle normer og værdier om kroppens distinktive sociale brug. Centralt står her normer og værdier om kroppens ypperlighed og fuldkommenhed, for at oversætte Defrances begreb $»$ Léxcellence corporelle «. ${ }^{12}$ ) Derved skabes en kropslig symbolik og en synliggørelse af sociale værdier, ligesom værdier og normer inderliggores og kropsliggøres. Derved bliver gymnastikken og idrætten i stand til at udtrykke en kulturel og eventuelt en politisk identitet, ikke som en direkte refleks af produktionslivets normer, men indirekte og gennem en række formidlende led. Kropskulturen i dens forskellige former må derfor ses som en relativ selvstændig kulturel dannelse, der gennem aktiviteter, institutioner og processer skaber betydning, symboler og identitet i forbindelse med kroppens sociale brug.

Fra slutningen af 1800-tallet og igennem forrige århundrede etableres der mere og mere selvstændige og moderne former for distinkte kropskulturer. Gymnastikken og sporten er de dominerende. Ud fra en historisk-sociologisk synsvinkel kan man se dette som en autonomiseringsproces.

\section{Selvstaendiggørelse og institutionalisering}

I begyndelsen af det 20 . århundrede var der allerede sket en betydelig institutionalisering af sporten og idrætten, omend på forskellig måde. For sportens vedkommende var det sket gennem dannelse af klubber, foreninger og organisationer, gennem standardisering af regler og love og gennem præcisering af amatørregler. Den Olympiske bevægelse blev den mægtigste drivkraft til en yderligere institutionalisering og autonomisering. Som bekendt var der $\mathrm{i}$ de forste årtier af de Olympiske Lege en broget mangfoldighed af aktiviteter, hvoraf mange måtte udskilles. For gymnastikkens vedkommende var udviklingen langt mere nationalt bestemt.

Den »gymnastiske konfiguration « som defineret for var langt mindre entydig. Svensk, tysk og dansk gymnastik var forskellige med hensyn til ovelsernes udformning og karakter, med hensyn til de kropslige og pædagogiske effekter, og med hensyn til normer og værdier. De forskellige systemers »gymnastikkultur« var forbundet med forskellige institutioners og sociale gruppers politiske, sociale og kulturelle kamp. For Danmarks vedkommende skete selvstændiggorelsen og institutionaliseringen gennem denne kulturkamp og var et resultat af kampen for kulturel og politisk dominans.

Den svenske gymnastiks sejr i begyndelsen af det 20. århundrede er et eksempel på et gymnastiksystems institutionalisering. Den blev enerådende i skolen, hæren, i den frivillige gymnastik på landet og i hæren. ${ }^{13}$ ) Selvstændiggørelsen og autonomiseringen for gymnastikkens vedkommende kan ses som 

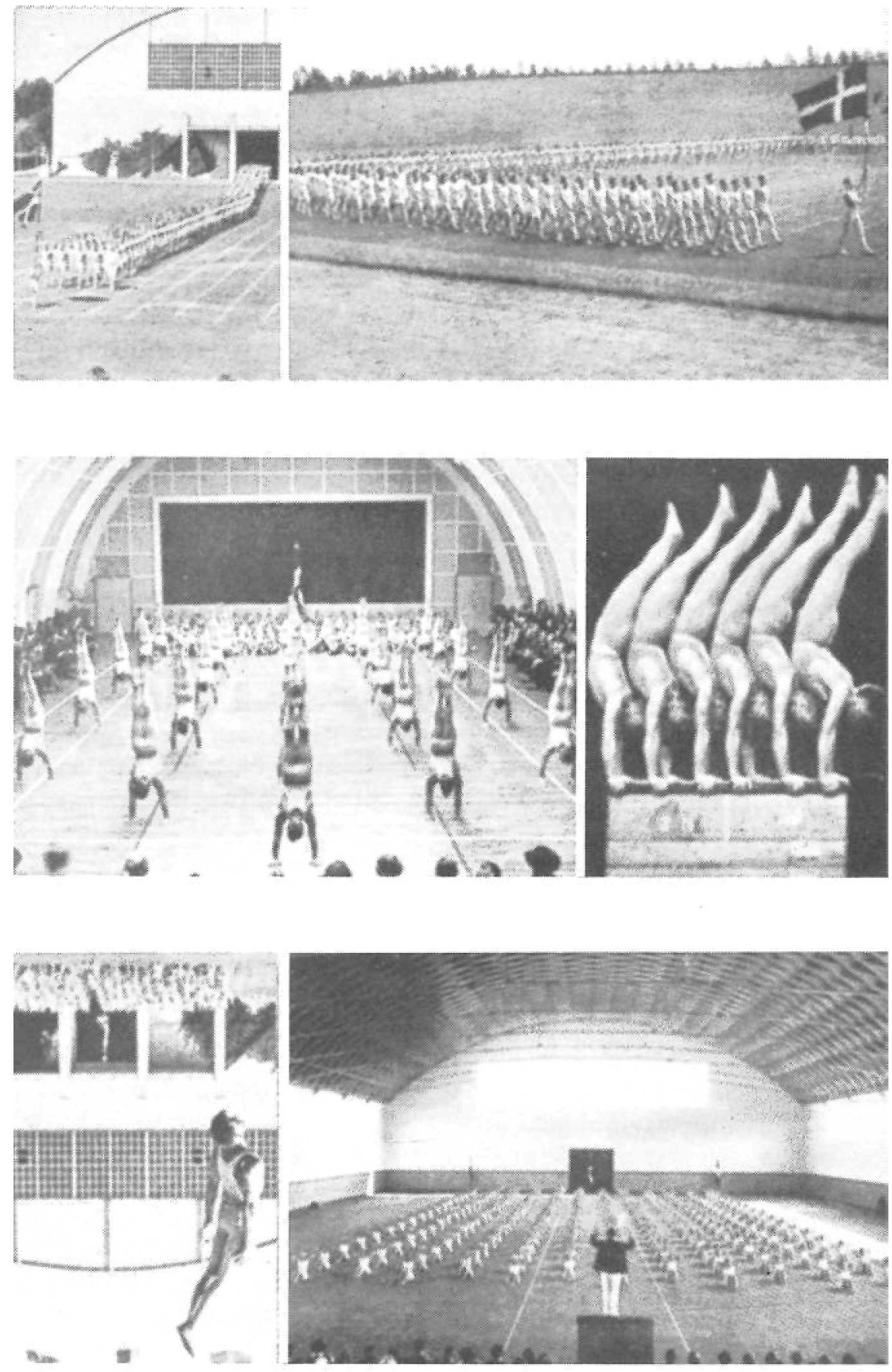

: is ${ }^{*} \quad \mathbf{P}$

"Niels Bukhs Ollerup-gymnastik« 
en proces, der omfatter en rakke størrelser. Der sker en specifikation af de gymnastiske mål og værdier (»legemlig fuldkommenhed «). Der udarbejdes særlige ovelser. Disse øvelsers særlige anatomiske og pædagogiske effekter præciseres. Der sker en afgrænsning i forhold til andre systemer. Systemet henvender sig til eller tillempes forskellige grupper. Særlige uddannelsesinstitutioner etableres med professionel ekspertise. Der etableres et uddannelsesnetværk, hvor igennem systemet spredes. Der sker en kodificering igennem lærebøger, håndbøger og øvelsesvejledninger. Endelig spredes systemet gennem opvisninger, stævner, konkurrencer o.l. Eventuelt sker der en internationalisering. Som bekendt var den svenske gymnastik allerede etableret som gymnastiksystem for introduktionen i Danmark, det vil sige, at den i Sverige havde gennemløbet de første faser. Den måde, institutionaliseringen foregår på igennem alle led kan variere meget, hvad den svenske gymnastiks skæbne i de forskellige skandinaviske lande er et godt eksempel pă.

I Danmark var resultatet, at den svenske gymnastik i en modificeret form vandt en vis grad af institutionalisering $\mathrm{i}$ dette århundredes forste årti. Dens sociale substrat var bondebefolkningen. Den folkelige gymnastik var organiseret i skytteforeningerne. I uddannelsesnetværket var hojskolernes undervisning centralt, ikke mindst gennem etableringen af delingsforerafdelinger ved en række højskoler. Men gymnastikken havde kun opnået en ringe grad af selvstændighed. Den var bundet til det forrige århundredes nationale og politiske kamp gennem Skyttebevægelsen. Den var defineret i opposition til sportens værdigrundlag, præstation og individualisme. De Danske Skytteforeningers ideologiske grundlag smuldrede, og skyttebevægelsens monopol blev truet af gymnasternes krav om repræsentation og anerkendelse.

\section{En magisk formel - en folkegymnastik og en folkeidrat}

Den danske højskole importerede et færdigt og kodificeret gymnastiksystem i 1884 og gjorde det til symbolet på grundtvigiansk legemskultur, med stort held. Niels Bukh havde slægtsrødder i højskolebevægelsen og vendte efter få års fravær tilbage. Hvad lå der bag hans ambition om at søge den rationelle kærne i den Lingske gymnastik? Hvad var den tryllekunst, som troldmanden fra Ollerup beherskede, så den kunne forbinde det frivillige delingsførerarbej de under primitive forhold $i$ et landsogn med fremvisningen af en dansk perfektionistisk bondegymnastik ved de Olympiske Lege, i Europa og på Verdensturneer?

Spørgsmålet antyder mulige svar. Den Lingske gymnastik i dens systematiske form havde stort set sejret $i$ det forste årti af det 20. århundrede. Et bevis for sejren leverede Niels Bukh i og for sig selv ved at vinde solv i Stockholm med et konkurrencehold i 1912. Endnu så kort tid efter den endelige sejr, og inden en korrekt svensk gymnastik formentlig var trængt ud i den yderste afkrog, fik han inspiration til en gymnastisk med-og modxevolution fra Elli Bjørkstens opvisning. Bevægelsesgymnastikken og dens formmæs- 
sige perfektionering må have været en dyb åbenbaring. Inspirationen fra Hebért i Frankrig pegede mod eksperimenter. Niels Bukh forkastede efter m $\varnothing$ det det Lingske systems normer og indledte i 1915 som leder for sin egen delingsforerafdeling en periode med eksperimenter. Resultatet blev en ny, tempopræget bevægelsesgymnastik, den primitive gymnastik. Efter datidens forhold, som K. A. Knudsen bevidner, var det en eksperimenterende periode med en forkastelse af hævdvundne principper og arbejdsformer. ${ }^{14}$ ) Samtidighed $\mathrm{i}$ ovelserne og formkrav forsvandt $\mathrm{i}$ jagten på det, Bukh senere kaldte den lingske gymnastiks kærne. Ambitionen var at befri den Lingske ide fra det Lingske gymnastiksystems systematik. Denne formel gjorde Niels Bukh til både traditionsfornyer $\mathrm{g}$ traditionsbevarer. Da denne formel var fundet med grundgymnastikken kunne han så at sige være mere Lingsk end den svenske gymnastiks tilhængere, især da han bevarede den svenske stiUingsgymnastik i sin »idrætsgymnastik«.

Han kunne gennem grundgymnastikkens arbejdsformer vise resultater. Modstanden mod den primitive gymnastik blev gradvist overvunden. I slutningen af tyverne kunne han så at sige sejrrigt henvise til moderation. Den magiske formel bestod i nyskabelsen, grundgymnastikken, som forste led i den legemlige opdragelse, kombineret med idrætsgymnastikkens to grene, nemlig stillingsgymnastikken og springøvelser. Han kunne henvise til, at han ikke forkastede, men uddybede og forbedrede. Som de indledende citater viser, kunne han ligeledes henvise til sportens værdier, hvis sporten blev befriet for konkurrence- og præmiejagt. Den magiske formel åbnede for sportens værdier. Ligesom de gymnastiske ovelser ikke var noget i sig selv, men kun. under ledelse i forhold til legemlige og pædagogiske idealer, var sportens værdier umiddelbare og brugbare. Niels Bukh sa en kærne af umiddelbarhed og begejstring, der kunne befries og kultiveres, og han så en grov og voldsom form, der skulle forkastes. Formlen for den frie idræts og boldspillenes kombination med hans egen grundgymnastik var fundet. Folkegymnastikken kunne kombineres med folkesporten.

Formlen for den Bukske tanke- og arbejdsgang var at forbinde et øvelsessystem eller en sportsforms elementære muligheder med en ledelsesmæssig og kulturel prægning. Det var kærnen i hans pædagogik.

\section{Autonomisering}

Nøglen til forståelsen af Niels Bukhs gymnastiske systems og gymnastiske stils position ligger $\mathrm{i}$, at han må betragtes som eksponent for gymnastikkens autonomisering i historisk-sociologisk forstand. Denne selvstændiggorelse af gymnastikken som et udtryk for legemets ypperlighed og perfektion kan demonstreres på flere måder.

For det forste frigor gymnastikken sig fra sin politisk-kulturelle binding til skyttesagen allerede i slutningen afFørste Verdenskrig, hvilket er velkendt. 
Det var denne proces, der forte til organisationsstridigheder, justeringer og brud, der kom til at præge hele perioden fra 1920 til 1950. Grunden til at Niels Bukhs gymnastik og hans person fik en så central rolle i den proces var $i$ al sin enkelthed, at han om nogen repræsenterede denne autonomisering.

For det andet demonstrerede gymnastikken sin egenart og berettigelse, sin autonomi i forhold til den position, den hidtil havde haft i højskolebevægelsen ved, at Niels Bukh oprettede en gymnastikhøjskole i 1920. Gennem oprettelsen af denne hojskoleform, viet til det gymnastiske arbejde, men med bevarelsen af traditionelle højskolefag og utvivlsomt i forlængelse af højskolebevægelsens bestræbelse på at forholde sig til og præge samtlige tidens kulturelle foreteelser, tog Niels Bukh konsekvensen af hojskolens adoptering af den svenske gymnastik siden 1880 'erne. Han skabte sin egen gymnastik i en videreudvikling af den Lingske. Han gav den en ny plads, ikke blot som en del af højskolens aktiviteter (1884 -1903) eller i form af delingsforerafdelingen siden 1903, men som en central del. Gymnastikken fik en gymnastikhøjskole. Dette muliggjorde et langt mere intensivt arbejde, der hverken kunne karakteriseres med begreberne professionel eller amator, men snarere med udtrykket »entusiast«. Det socio-økonomiske grundlag forblev bønderne, men med etableringen af en gymnastikhøjskole skabtes der mulighed for en rendyrkelse og perfektionering i forhold til højskolens hidtidige satsning på gymnastikken. Her blev hans egen nyskabelse, grundgymnastikken, vigtig, fordi denne arbejdsform muliggjorde resultater i bred forstand, der synliggjorde gymnastikken som kulturfaktor.

For det tredie viste dette gymnastiksystem og denne gymnastiske stil sig i stand til at slå igennem internationalt, og ikke blot i Danmark. Gennem den intensive opvisnings- og turnévirksomhed, gennem kursusvirksomhed for gymnastikpædagoger fra mange lande, gennem udenlandske elever og gennem datidens mediedækning kunne Niels Bukh fremvise en perfektionistisk gymnastikform, der vakte international anerkendelse. Det blev et symbol for, hvad dansk gymnastik formåede i den gymnastiksystemernes videreudvikling mod nye udtryksformer, der karakteriserede mellemkrigstiden.

Det geniale i Niels Bukhs arbejde bestod $i$ at kombinere den primitive gymnastiks intensive arbejdsform og evne til at skabe resultater med en opvisningsgymnastik, der i en vis forstand var eklektisk, idet han her benyttede såvel den svenske gymnastik som redskabsgymnastik.

For det fjerde tillod Gymnastikhøjskolens arbejdsform at forene to ting, der umiddelbart syntes modstridende. Den gjorde det muligt i een og samme proces at uddanne tusindvis af delingsforere til et folkeligt gymnastikarbejde under mere eller mindre primitive forhold på landet, idet den primitive gymnastik af Bukh direkte var udtænkt til manglen på faciliteter, og til at fremvise elitegymnastik på datidens internationale topplan.

For det femte kunne denne rendyrkede eller autonome gymnastik hævde sig overfor den internationale sport gennem stævner, landsfester og Olympiske Lege, eller internationale gymnastikfester som de to Lingiader. Denne 
gymnastik så sig selv som overlegen eller af samtidens medier og opinion som ligeberettiget $\mathrm{i}$ forhold til sporten.

Alt $i$ alt synes det berettiget $i$ en historisk-sociologisk analyse af gymnastikken, specielt den Bukhske, at karakterisere den som udtryk for en specifik autonomiseringsproces i mellemkrigstiden. Hele konfigurationen, fra ovelser, koreografi, organisation og selvforståelse, og finansering gor det rimeligt at hæfte sig ved denne selvstændiggørelse, der naturligvis hænger tæt sammen med Bukhs personlige egenskaber som leder og organisator.

\section{Noter}

1. N. Bukh: Dansk - primitiv - Gymnastik. 1936. Afslutning.

2. Danmarks Folkehøjskole 1844 -1944. København 1944, s. 197.

3. N. Bukh: Primitiv Gymnastik. Odense 1922, s. 6.

4. Sst. s. 6.

5. Sst. s. 140 .

6. Sst. s. 140

7. Sst. s. 141 .

8. N. Bukh: Dansk - primitiv - Gymnastik. 1936, s. 76.

9. Sst. s. 4.

10. K. Krogshede: Minder fra Ollerup og Gerlev. 1980, s. 163.

11. N. Bukh: Primitiv Gymnastik, s. 143.

12. J. Defrance: Léxcellence Corporelle. Rennes 1987.

P. Bourdieu: La Distinction. Paris 1979

P. Bourdieu: Questions de Sociologie, Paris 1984, s. 181.

13. O. Korsgaard: Kampen om Kroppen. København 1982, s. 226.

14. K.A. Knudsen: Gymnastikkens udvikling i Danmark. I Fri Ungdom, red. J. Bukdahl og J. Marinus Jensen. Odense 1944, s. 164.

\section{Litteraturliste:}

Bourdieu, Pierre (1979) »La Distinction«, Paris.

Bourdieu, Pierre (1984) »Question de Sociologie«, Paris.

Bukh, Niels (1922) »Primitiv Gymnastik«, Odense.

Bukh, Niels (1936) »Dansk - primitiv - Gymnastik «,

Bukdahl, J. og Jensen, J. Marinus (red.) (1944)»Fri Ungdom«, Odense 1944.

»Danmarks Folkehøjskole 1844-1944« (1944), København.

Defrance, J. (1987) »Løexcellence Corporelle«, Rennes.

Korsgaard, Ove (1982) "Kampen om kroppen «, København.

Krogshede, K. (1980) »Minder fra Ollerup og Gerlev«,

\section{Søren Damkjær}

Lektor ved Institut for Kultursociologi, Københavns Universitet. 